\title{
Designing a physical education and sports diploma program for sports recreation specialists working in disability field in accordance with quality criteria
}

\author{
Bassem Mohamed Tohamy \\ Associate professor, Faculty of Physical Education, Helwan University
}

\section{Introduction and research problem}

Working human resources are considered the basis of nations' advancements. They assist in achieving success of societal development in a changing context which requires a competitive performance and high quality in higher education. Since there is an increase in individuals' numbers engaging in higher education institutions and programs, higher education has to develop individuals' skills and create new specialties which corresponds to recent requirements. Accordingly, this will create a new workforce that has the necessary efficiencies and experiences (9: 6,15).

There is a rapid increase in knowledge; accordingly, business requirements, structure and distribution of workforce are changing. The increase demand for skillful workforce and service and information professions, the change of business technology, and women role in business as well as the steady increase of unemployment among youth who do not have qualifications required by business market have all led to the need to plan programs in a professional way. Accordingly, universities are developing studying and training programs to respond to the ongoing changes in business environment. Building on this, the current study aims to investigate the academic preparation for sports recreation program for disabled to be the base upon which disabled recreation activities are built $(1: 25,27)$.

Recreation is one of the fields that assist in building personality of people with special needs since it provides opportunities to express their identity, capabilities, creativity. It is also considered a field which provides various activities that respond to the child's movement needs, meditation, and creativity. In this concern, El-Hamahmy and Ayda Abdeaziz, (1998) indicate that recreation provides child with experiences and information spontaneously (11: 160).

Tahany Abdelsalam, (2000) added that practicing activities assist in feeling happiness, proud of achieving a certain job (4: 245).

The twenty century witnessed important initiatives for caring about people with special needs and attention has been paid to the problems they are facing through holding conferences, seminars, carrying out studies and scientific research to respond to their special needs and doing efforts to qualify this segment to face difficulties in their societies.

The society's care of people with special needs is considered an important criterion upon which the society's advancement is assessed. In order to enable intellectually disabled people to interact socially and cope with life needs, it is important to provide them with equal opportunities to support their inclusion in social life. Therefore, it is essential to qualify graduates who specialize in sports recreation and work in the disability field through specialized academic institutions. Accordingly, the researcher aims at designing a physical education and sports diploma program for sports recreation specialists who work in disability field in accordance with quality criteria. 


\section{Research objectives}

The current research aims to design a physical education and sports diploma program for sports recreation specialists who work in disability field in accordance with quality criteria.

\section{Previous literature}

1- The study of "Mohamed Sayed Hashim, 2010" entitled "Building Sports For All programs in accordance with total quality criteria". This study aims to design a list of criteria of sports for all quality programs. The researcher used a descriptive methodology "Analytical approach" and designed a list to shed light on scientific criteria that should be considered in planning Sports for All programs. The researcher also selected a purposive sample (170 participants) of staff working in sports recreation departments in faculties of physical education as well as individuals working in the field of Sports for All and those who are involved in planning Sports for All programs in the National Council of Sports as well individuals working in quality assurance units. The study concludes the importance that "Sports for All" institution message reflects the nature of the programs offered and the targeted audience as well as the importance of setting programs' objectives according to the practitioners' needs to be applicable and measurable objectives. The study revealed also the significance of participation of practitioners in the evaluation process.

2- The study of "Amal Gamil Youssef and Mohamed Abdelsalam, 2001" titled "professional development of newly (fresh graduates) Sports for All graduates in accordance with business market requirements". The study aims at planning a proposed program for a professional development of new Sports for All graduates through identifying professional development needs according to the needs of business market, organizational aspects and contents of the proposed program as well as implementation methods, criteria and skills that should be available in trainers involved in the proposed program as well as evaluation methods. The researchers used descriptive methodology and analytical approach and deigned a research questionnaire to collect data. The research sample was a purposive sample consisting of (100) specialists. The key findings of this study identified the basic needs of professional development of Sports for All specialists and built a professional development program of new graduates Sports for All graduates in accordance with business market requirements; this includes the program title, program objectives, time frame, targeted segment, enrollment rules and conditions, program contents (this involves theoretical topics, practical application, implementation methods, criteria and skills that should be available in program's trainers and program evaluation methods). The study recommends re-considering programs of professional development provided to Sports for All specialists as well as the importance of considering the needs and requirements of business market when planning and implementing future professional development programs.

3- The study of "Benjamin Jeffry Hartnell, 2011" titled "Criteria of building and evaluating curriculum and teaching methods". The study aims at assessing the effect of teaching and learning methods on educational curriculum in higher education schools. The researcher indicated that the performance criteria used as the independent variable and that the students achievement as the dependent variable. The researcher used the experimental methodology to compare two groups in this concern. The study reveals that resulted criteria could be used to assess the effectiveness of curriculum and methods used in teaching. Moreover, these criteria could be 
considered measures and indicators that instructors should use to assess learning outcomes and students' achievements and to evaluate the effectiveness of curriculum used in teaching.

4- The study of " $"$ " titled "a proposed curriculum for recreational tourism for students enrolled in faculty of physical education (recreation department)". The study aims at proposing a curriculum for students enrolled in faculty of physical education, recreation department. The study aims at qualifying a staff who works in the tourism field. The researcher used a descriptive methodology and used a purposive sample of experts in recreation field, tourism and teaching methods (30 experts), and a random sample of students enrolled in recreation department, Faculty of Physical Education (423 students). One of the key findings of the study is proposing a curriculum of recreational tourism consisting of: history of tourism and its development, tourist definition, tourism definition, the concept of tourism industry, importance of tourism, economic impacts of tourism, the factors affecting tourism movement, the relation between recreation and tourism, tourism motivations, tourist attractions, tourism natural resources, tourism types, recreational tourism, recreational tourism resorts and institutions, recreational tourism activities, Safari tours and desert tourism, recreational tourism festivals, protocol rules and hospitality essentials, Egypt tourism geography, and international, regional and local tourism organizations.

5- The study of " (يمان رفعت السعيد (r.|r" titled "the effectiveness of a proposed program to qualify sports recreation specialists". The study aims at identifying the effectiveness of a proposed program to qualify sports recreation specialists. The researcher used the descriptive methodology and analytical approach. The researcher designed a survey questionnaire to assess the program effectiveness using a sample of (135) sports specialists. The study results indicates that the sports specialists lacks certain professional and scientific skills represented in their abilities to plan and manage recreation projects and programs to match recent trends. Moreover, the results revealed that sports' specialists lack particular general skills which relate to mastering reports writing basic rules in an appropriate way as well as presenting these reports using technological methods. Furthermore, the study findings revealed the weak level of the program's teaching and learning methods.

\section{Research procedures}

Research methodology: the researcher used the descriptive methodology.

Research society: the society consists of Faculty of Physical Education graduates, Helwan University whose specialty is sports recreation and who have been graduated in the following years (2014-2015, 2015-2016, 2016-2017) as well as those who work in the disability field.

Research sample: the researcher used a random sampling technique. The sample includes (132) participants of Faculty of Physical Education graduates who enrolled in sports recreation department since 2014 to 2017.

\section{Data collection}

The tools that were used to collect research data include:

- A research questionnaire that has been designed including a proposed physical education and sports program for sports recreation specialists working in the disability field in accordance to quality criteria "attachment 2". The following steps have been employed in developing the questionnaire: 
1- Six dimensions have been identified based on previous related literature "attachment 3".

2- The six dimensions have been presented to 11 experts in the field of sports recreation and quality "attachment 1 " to determine the face validity and content validity and its relevance to the topic. 85 percent was used as a cut-point for their aggregated scores to retain the items. (Table 1).

Table (1) Percentages of experts' opinions regarding the proposed program's constructs

\begin{tabular}{|c|c|c|c|c|}
\hline & Program constructs & Relevant & Irrelevant & Percentage \\
\hline 1 & $\begin{array}{c}\text { The objectives of the proposed physical education } \\
\text { and sports program for sports recreation specialists } \\
\text { working in the disability field }\end{array}$ & 10 & 1 & $90.9 \%$ \\
\hline $\begin{array}{c}\text { Targeted educational outcomes of the proposed } \\
\text { physical education and sports program for sports } \\
\text { recreation specialists working in the disability } \\
\text { field: }\end{array}$ & 11 & 0 & $100 \%$ \\
\hline 3 & $\begin{array}{c}\text { Knowledge and understanding } \\
\text { b- Mental skills }\end{array}$ & 11 & $100 \%$ \\
\hline $\begin{array}{c}\text { contents of the proposed physical education and } \\
\text { sports program for sports recreation specialists } \\
\text { and the disability field, acceptance policy } \\
\text { and requirements of enrollment }\end{array}$ & $\begin{array}{c}\text { Working fields of the proposed physical education } \\
\text { and sports program for sports recreation specialists } \\
\text { working in the disability field }\end{array}$ & 11 & 0 & $100 \%$ \\
\hline 5 & $\begin{array}{c}\text { Teaching and learning methods that will be } \\
\text { employed in the proposed physical education and } \\
\text { sports program for sports recreation specialists } \\
\text { working in the disability field }\end{array}$ & 11 & 0 & $100 \%$ \\
\hline $\begin{array}{c}\text { Evaluation methods of the proposed physical } \\
\text { education and sports program for sports recreation } \\
\text { specialists working in the disability field }\end{array}$ & 11 & 0 & $100 \%$ \\
\hline
\end{tabular}

Additionally, the items of each construct have been presented to the experts as well to select the items that they consider relevant and to assess the relative importance for all items of the six dimensions (Attachment 4).

According to the experts' opinions, the items which have an acceptance of $75 \%$ or more among all experts have been retained. The items which the experts decided they are irrelevant to their specific constructs have been removed from further analysis (attachment 5). This stage of scale development resulted in an initial pool of 52 items.

Table (2) Items' numbers of each construct

\begin{tabular}{|c|c|c|}
\hline & Program constructs & $\begin{array}{c}\text { Number of items } \\
\text { in each construct }\end{array}$ \\
\hline 1 & $\begin{array}{c}\text { Objectives of the proposed physical education and sports program for } \\
\text { sports recreation specialists working in the disability field }\end{array}$ & 4 \\
\hline
\end{tabular}




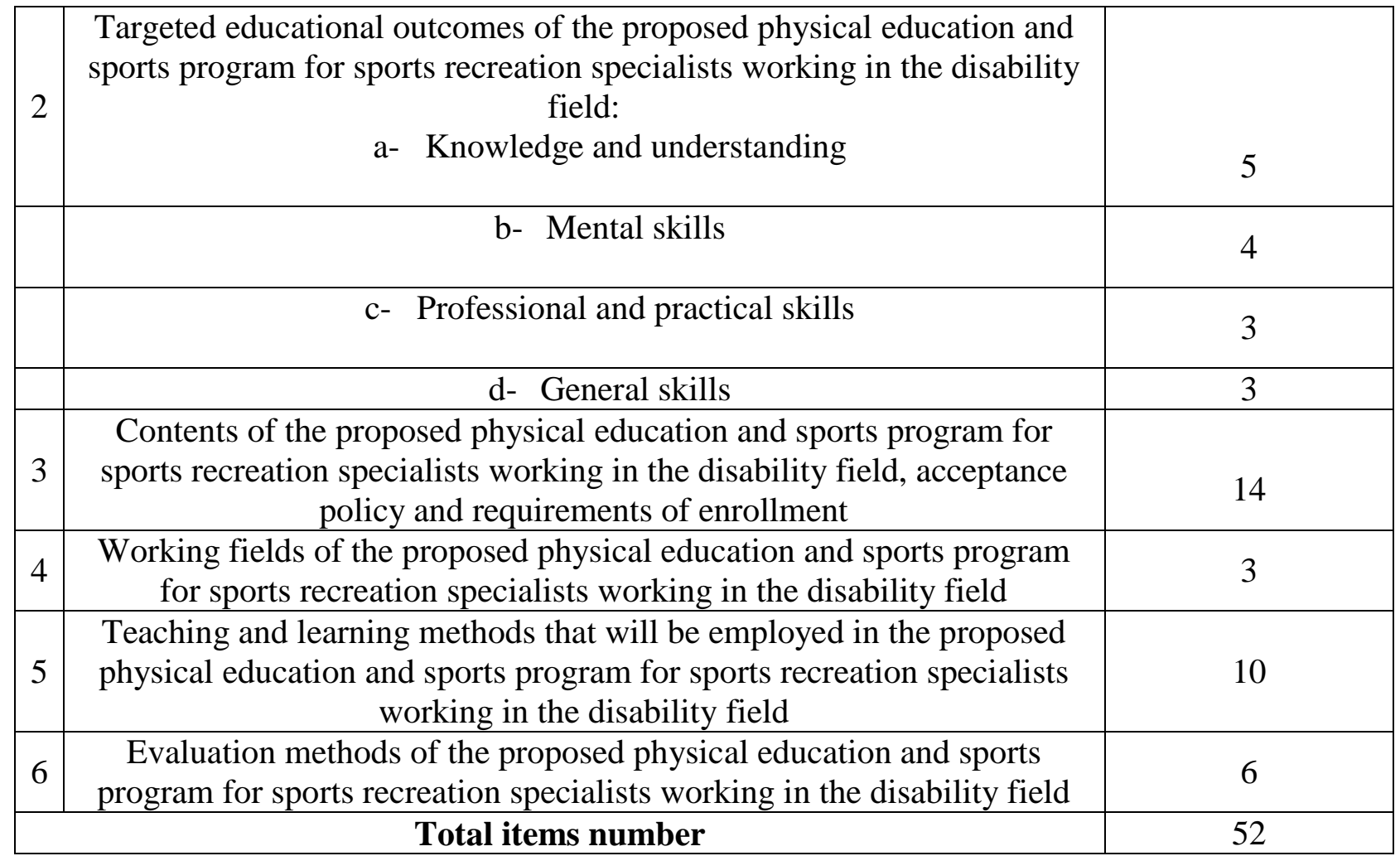

All items were measured on 3-point scale: relevant (three marks), relevant but has to be modified (two marks), irrelevant (one mark).

Internal consistency reliability: Internal consistency reliability was measured by assessing correlation coefficient between the item and the total marks of its construct. All items were statistically significant $(\mathrm{P}=0.05)$ which confirms the internal consistency reliability of all items (attachment 6).

Reliability: the researcher assessed reliability through calculating Cronbach's alpha values which range from 0.712 to 0.756 for all constructs of the proposed program which verify items reliability.

\section{Results and discussion}

Table (3) Frequencies, total scores, and percentages concerning objectives of the proposed physical education and sports program for sports recreation specialists working in the disability field. $(\mathrm{N}=132)$

\begin{tabular}{|c|c|c|c|c|c|c|}
\hline & \multicolumn{2}{|c|}{ Items } & \multicolumn{2}{|c|}{ Frequencies } & Total & Percentages \\
\cline { 2 - 4 } 1 & $\begin{array}{c}\text { Strongly } \\
\text { agree }\end{array}$ & Agree & Disagree & scores & A \\
\hline & $\begin{array}{c}\text { Understanding basics and } \\
\text { principles of sports leisure and } \\
\text { recreation of disabled }\end{array}$ & 215 & 58 & 9 & 770 & 91.0 \\
\hline $\begin{array}{c}\text { Identifying scientific basics to } \\
\text { build sports recreation } \\
\text { programs of disabled }\end{array}$ & 220 & 52 & 10 & 774 & 91.0 \\
\hline $\begin{array}{c}\text { Using ongoing self- } \\
\text { development of specialists' } \\
\text { professional and personal skills }\end{array}$ & 184 & 83 & 15 & 733 & 86.6 \\
\hline
\end{tabular}




\begin{tabular}{|c|c|c|c|c|c|c|}
\hline 4 & $\begin{array}{c}\text { Identifying required principles } \\
\text { to manage institutions serving } \\
\text { disabled }\end{array}$ & 234 & 37 & 11 & 787 & 93.0 \\
\hline
\end{tabular}

As illustrated in table (3) the response rate ranges from $86 \%$ to $93 \%$. The researcher argues that to perform appropriately, the specialists should be qualified professionally which could be achieved through designing a specialized program that is based on scientific principles and has clear and specific objectives. Moreover, the specialist should have the opportunity to exploit all his/her abilities to reach good results.

In this concern, Echevaria, (2000) and Carole, (2003) confirmed the importance of engaging program's beneficiaries in setting up the program's objectives that will assist in improving his/her performance according to recent sports requirements and to be trained on self-learning methods to achieve the optimal performance in work.

Table (4) Frequencies, total scores, and percentages regarding targeted educational outcomes of the proposed physical education and sports program for sports recreation specialists working in the disability field: $(\mathrm{N}=132)$

\begin{tabular}{|c|c|c|c|c|c|c|}
\hline & \multirow[b]{2}{*}{ Items } & \multicolumn{3}{|c|}{ Frequencies } & \multirow{2}{*}{$\begin{array}{l}\text { Total } \\
\text { scores }\end{array}$} & \multirow[b]{2}{*}{ Percentages } \\
\hline & & $\begin{array}{l}\text { Strongly } \\
\text { agree }\end{array}$ & Agree & Disagree & & \\
\hline & $\begin{array}{l}\text { Knowledge and } \\
\text { understanding }\end{array}$ & & & & & \\
\hline 1 & $\begin{array}{l}\text { Mention mission's laws and } \\
\text { ethics concerning sports } \\
\text { recreation for disabled }\end{array}$ & 100 & 22 & 10 & 354 & 89.4 \\
\hline 2 & $\begin{array}{l}\text { Determine concepts and recent } \\
\text { trends regarding leisure and } \\
\text { recreation for disabled }\end{array}$ & 105 & 16 & 11 & 358 & 90.4 \\
\hline 3 & $\begin{array}{l}\text { Identify the scientific basics } \\
\text { used in building up sports } \\
\text { recreation programs for disabled }\end{array}$ & 103 & 20 & 9 & 358 & 90.4 \\
\hline 4 & $\begin{array}{l}\text { clarify the role and contributions } \\
\text { of leaders volunteering in } \\
\text { providing recreational services } \\
\text { for disabled }\end{array}$ & 109 & 19 & 4 & 369 & 93.2 \\
\hline 5 & $\begin{array}{c}\text { Identify social legal aspects and } \\
\text { legislations concerning } \\
\text { disabled }\end{array}$ & 110 & 13 & 9 & 365 & 92.2 \\
\hline & Mental skills & & & & & \\
\hline 6 & $\begin{array}{l}\text { Summarize key requirements of } \\
\text { sports recreation specialists who } \\
\text { work in the disability field }\end{array}$ & 107 & 19 & 6 & 365 & 92.2 \\
\hline 7 & $\begin{array}{l}\text { Analyze problems that relate to } \\
\text { sports recreation for disabled } \\
\text { and propose appropriate } \\
\text { solutions and alternatives }\end{array}$ & 90 & 29 & 13 & 341 & 86.1 \\
\hline 8 & $\begin{array}{l}\text { Select suitable methods and } \\
\text { tools to evaluate sports } \\
\text { recreation for disabled and } \\
\text { propose development methods }\end{array}$ & 88 & 40 & 4 & 348 & 87.9 \\
\hline
\end{tabular}




\begin{tabular}{|c|c|c|c|c|c|c|}
\hline 9 & $\begin{array}{c}\text { Clarify ways of protecting } \\
\text { disabled from health problems } \\
\text { during carrying out recreation } \\
\text { programs }\end{array}$ & 99 & 22 & 11 & 342 & 88.9 \\
\hline & $\begin{array}{l}\text { Professional and } \\
\text { practical skills }\end{array}$ & & & & & \\
\hline 10 & $\begin{array}{c}\text { apply the scientific method in } \\
\text { solving problems that might } \\
\text { encounter disabled during } \\
\text { carrying out recreation } \\
\text { programs }\end{array}$ & 92 & 24 & 16 & 340 & 85.9 \\
\hline 11 & $\begin{array}{l}\text { Comply with mission moralities } \\
\text { in dealing with disabled }\end{array}$ & 91 & 31 & 10 & 345 & 97.1 \\
\hline \multirow[t]{2}{*}{12} & $\begin{array}{c}\text { Plan to market recreation } \\
\text { programs and services designed } \\
\text { for disabled }\end{array}$ & 111 & 15 & 6 & 369 & 93.2 \\
\hline & $\begin{array}{c}\text { General skills } \\
\end{array}$ & & & & & \\
\hline 13 & $\begin{array}{l}\text { Use advanced technological } \\
\text { tools in carrying out disabled } \\
\text { recreational sports }\end{array}$ & 92 & 21 & 19 & 337 & 85.1 \\
\hline 14 & $\begin{array}{c}\text { Acquire effective } \\
\text { communication skills with } \\
\text { individuals working in places } \\
\text { where recreation programs are } \\
\text { offered to disabled (targeted } \\
\text { segments-workers- } \\
\text { administrators) }\end{array}$ & 101 & 21 & 10 & 355 & 89.6 \\
\hline 15 & $\begin{array}{l}\text { Setting up partnerships, } \\
\text { agreements and setting } \\
\text { cooperative relationships with } \\
\text { institutions that care about } \\
\text { disabled }\end{array}$ & 100 & 20 & 12 & 352 & 88.9 \\
\hline
\end{tabular}

As illustrated in table (4), the response rates of participants range from $85.1 \%$ to $93.2 \%$. This may due to the importance for sports specialists to have the necessary knowledge and concepts associated with disability field which assist in forming his/her knowledge structures that relates to understanding the frameworks which enable sports recreation sports to practice his/her work appropriately. Furthermore, it enables the specialists to develop their skills of analyzing, differentiating, evaluating, classifying, deducting, and creation in light of gained information as well as their abilities to propose solutions to problems they may encounter in planning and implementing sports recreation programs. Moreover, it is important for individuals working in disability field to learn attitudinal patterns which enable them to interact with others working with them and also practitioners who have disabilities. Similarly, it is significant to develop their abilities to use advanced technological tools in carrying out recreation programs and abilities of registering and analyzing data. This is consisting with Mohamed Mohamed Elhamahmy and Amin Elkouly (2001) who indicated that the physical education programs seek to keep up scientific advancements which distinguish the current time. Accordingly, the structure of these programs depends on recent scientific, educational and social basics which contribute in meeting individuals and society's needs, thus adopting society's educational philosophy (12:37). 
In this regard, the criteria of accreditation council (COA, 2004) point out to the ability to implement the current technology on professional practices separately and this include technology examples: writing reports, segment programs, data base management, presentations, graphic programs as well as creating web pages.

Table (5) Frequencies, total scores, and percentages concerning contents of the proposed physical education and sports program for sports recreation specialists working in the disability field: $(\mathrm{N}=132)$

\begin{tabular}{|c|c|c|c|c|c|c|c|}
\hline & \multirow{2}{*}{$\begin{array}{c}\text { Code } \\
\text { and } \\
\text { number }\end{array}$} & \multirow[b]{2}{*}{ Items (course name) } & \multicolumn{3}{|c|}{ Frequencies } & \multirow[b]{2}{*}{$\begin{array}{c}\text { Total } \\
\text { scores }\end{array}$} & \multirow[b]{2}{*}{ Percentages } \\
\hline & & & $\begin{array}{c}\text { Strongly } \\
\text { agree }\end{array}$ & Agree & Disagree & & \\
\hline 1 & $\begin{array}{l}\text { C.M } \\
501\end{array}$ & $\begin{array}{c}\text { Basics of physical } \\
\text { education }\end{array}$ & 109 & 16 & 7 & 366 & 92.4 \\
\hline 2 & P.S 501 & $\begin{array}{c}\text { Measurement and } \\
\text { evaluation in physical } \\
\text { education }\end{array}$ & 102 & 24 & 6 & 360 & 90.9 \\
\hline 3 & R.S 501 & $\begin{array}{c}\text { Disabled rights } \\
\text { (mandatory) }\end{array}$ & 84 & 37 & 11 & 337 & 85.1 \\
\hline 4 & R.S 502 & $\begin{array}{l}\text { Legislations and ethics } \\
\text { when communicating } \\
\text { with disabled } \\
\text { (mandatory) }\end{array}$ & 110 & 20 & 2 & 372 & 93.9 \\
\hline 5 & R.S 503 & $\begin{array}{l}\text { Quality of recreation } \\
\text { services offered to } \\
\text { disabled (mandatory) }\end{array}$ & 93 & 31 & 8 & 349 & 88.1 \\
\hline 6 & R.S 504 & $\begin{array}{l}\text { Strategic planning of } \\
\text { sports recreation } \\
\text { programs for disabled } \\
\text { (mandatory) }\end{array}$ & 92 & 26 & 14 & 342 & 86.4 \\
\hline 7 & R.S 505 & $\begin{array}{c}\text { Nutrition and wellness } \\
\text { of disabled } \\
\text { (mandatory) }\end{array}$ & 107 & 18 & 7 & 364 & 91.9 \\
\hline 8 & R.S 506 & $\begin{array}{l}\text { Contemporary issues } \\
\text { in recreation for } \\
\text { disabled (mandatory) }\end{array}$ & 110 & 20 & 2 & 372 & 93.9 \\
\hline 9 & R.S 507 & $\begin{array}{l}\text { Public relation of } \\
\text { sports recreation } \\
\text { specialists working in } \\
\text { disability field }\end{array}$ & 98 & 31 & 12 & 341 & 86.1 \\
\hline 10 & R.S 508 & Posture deviation & 99 & 26 & 7 & 356 & 89.9 \\
\hline 11 & R.S 509 & $\begin{array}{c}\text { Management of } \\
\text { institution serving } \\
\text { disabled (selective) }\end{array}$ & 104 & 18 & 10 & 358 & 90.4 \\
\hline 12 & R.S 510 & $\begin{array}{l}\text { Adjusting disabled } \\
\text { sports recreation } \\
\text { activities (selective) }\end{array}$ & 106 & 20 & 6 & 364 & 91.9 \\
\hline 13 & R.S 511 & $\begin{array}{c}\text { Disabled psychology } \\
\text { (selective) }\end{array}$ & 88 & 36 & 8 & 344 & 86.9 \\
\hline 14 & R.S 512 & Disabled recreation & 94 & 19 & 19 & 339 & 85.6 \\
\hline
\end{tabular}


games (selective)

As indicated in table (5), the response rates of participants range from $85.1 \%$ to $93.9 \%$. The researcher considers that it is important to the sports recreation specialists to know legislations and ethics when communicating with disabled identify quality of sports recreation offered to disabled as well as knowing the contemporary issues in recreation for disabled. Moreover, it is important to identify the way in which institutions caring about disabled are managed and also to adjust disabled sports recreation activities. In this respect, Mohamed Kamal Elsamanody, (2001) confirmed the importance of considering several changes in designing and building up the program, for instance the program should be in line with the organization message and that the program planning should be consistent with the strategic planning of the organization, it is important as well to engage targeted program segments in program planning because it is not possible to plan programs which are far from the real situation and the specific needs of the targeted program segments $(10: 67,68)$.

Table (6) Frequencies, total scores, and percentages concerning working fields of the proposed physical education and sports program for sports recreation specialists working in the disability field $(\mathrm{N}=132)$

\begin{tabular}{|c|c|c|c|c|c|c|}
\hline & Items & \multicolumn{2}{|c|}{ Frequencies } & \multirow{2}{*}{ Total } & \multirow{2}{*}{ Percentages } \\
\cline { 2 - 5 } & $\begin{array}{c}\text { Strongly } \\
\text { agree }\end{array}$ & Agree & Disagree & \\
\hline 1 & Disability schools & 112 & 15 & 5 & 371 & 93.7 \\
\hline 2 & $\begin{array}{c}\text { Youth centers and sporting } \\
\text { clubs (governmental-disabled } \\
\text { specific - private) }\end{array}$ & 107 & 18 & 7 & 364 & 91.9 \\
\hline 3 & NGOs & 100 & 22 & 10 & 354 & 89.4 \\
\hline
\end{tabular}

According to table (6), the response rates of participants range from $89.4 \%$ to $93.7 \%$. The researcher argues that it is important to have highly-qualified sports recreation specialists who specialize in disability field to work in different sectors.

Table (7) Frequencies, total scores, and percentages regarding teaching and learning methods that will be employed in the proposed physical education and sports program for sports recreation specialists working in the disability field. $(\mathrm{N}=132)$

\begin{tabular}{|c|c|c|c|c|c|c|}
\hline & \multirow{2}{*}{ Items } & \multicolumn{3}{|c|}{ Frequencies } & \multirow{2}{*}{$\begin{array}{c}\text { Total } \\
\text { scores }\end{array}$} & \multirow{2}{*}{ Percentages } \\
\cline { 3 - 5 } & $\begin{array}{c}\text { Strongly } \\
\text { agree }\end{array}$ & Agree & Disagree & & \\
\hline 1 & Theoretical lectures & 100 & 20 & 12 & 352 & 88.9 \\
\hline 2 & Workshops & 102 & 22 & 8 & 358 & 90.4 \\
\hline 3 & $\begin{array}{c}\text { Conversations and } \\
\text { discussions }\end{array}$ & 101 & 23 & 8 & 357 & 90.2 \\
\hline 4 & Seminars & 89 & 30 & 13 & 340 & 85.9 \\
\hline 5 & Brainstorming & 88 & 30 & 14 & 338 & 85.4 \\
\hline 6 & Self-learning & 91 & 26 & 15 & 340 & 85.9 \\
\hline 7 & Educational materials & 89 & 28 & 15 & 338 & 85.4 \\
\hline 8 & Electronic learning & 93 & 22 & 17 & 340 & 85.9 \\
\hline 9 & Distance learning & 95 & 26 & 11 & 348 & 87.9 \\
\hline 10 & Practical performance & 102 & 22 & 8 & 358 & 90.4 \\
\hline
\end{tabular}

As illustrated in table (7), the response rates of participants range from $85.4 \%$ to $90.4 \%$. The researcher considers that this might due to the relevance of these methods to the diploma stage which usually requires different teaching methods from those enrolled in the 
undergraduates' stage, the diploma stage requires providing the students the opportunity to express their ideas and perceptions and at the same time benefiting from staff's educational experiences.

In this regard, "Tamer Ahmed Abdelhamid, 2014" indicates that teaching and learning strategies from the quality perspective include some important strategies that should be applied consequently, these strategies are: Brain storming, competitive learning, cooperative learning, posing questions strategy, working in small groups, apply direct teaching strategy, understanding maps, structural learning and performance in groups (3: 73).

Table (8) Frequencies, total scores, and percentages concerning evaluation methods of the proposed physical education and sports program for sports recreation specialists working in the disability field $(\mathrm{N}=132)$

\begin{tabular}{|c|c|c|c|c|c|c|}
\hline & \multirow{2}{*}{ Items } & \multicolumn{3}{|c|}{ Frequencies } & \multirow{2}{*}{$\begin{array}{c}\text { Total } \\
\text { Scores }\end{array}$} & \multirow{2}{*}{ Percentages } \\
\cline { 3 - 5 } & $\begin{array}{c}\text { Strongly } \\
\text { agree }\end{array}$ & Agree & Disagree & & \\
\hline 1 & Study papers & 103 & 15 & 14 & 353 & 89.1 \\
\hline 2 & Case studies & 91 & 28 & 13 & 342 & 86.4 \\
\hline 3 & Project reports & 113 & 12 & 7 & 370 & 93.4 \\
\hline 4 & Mid-term exams & 106 & 18 & 8 & 362 & 91.4 \\
\hline 5 & Final term exam & 111 & 13 & 8 & 367 & 92.7 \\
\hline 6 & Practical exam & 115 & 12 & 5 & 374 & 94.4 \\
\hline
\end{tabular}

As clarified in table (7), the response rates of participants range from $86.4 \%$ to $94.4 \%$. This result may due to the ongoing evaluation of diploma students where several evaluation methods are followed for instance: assignments, tests, measures and personal observation, case studies, reports, analyze documents. The evaluation process should be a comprehensive evaluation process that encompasses students' evaluation as well as program evaluation according to its objectives, its suitability to recent changes and society needs and also evaluation the institution itself based on international criteria to assess performance.

In this concern, "Sally Saied Abdo, 2014" as revealed in "Amin Elkhouly and Gamal Eldien Elshafie, 2001) indicates that programs' evaluation achieve many objectives; for instance: revising programs and courses to develop aspects that need to be modified in light of educational aims that have been achieved. This could be done through assessing the students' overall performance and through the perspective of "speed or slow of implementing learning objectives procedures", the ease or difficulty of the educational material, the material being interesting or not, and relation between contents and educational objectives (6:153).

\section{Conclusion}

The current study proposed a physical education and sports program designed for sports recreation specialists working in disability field in accordance with the quality criteria. The proposed program includes 6 constructs with 52 items as follows: the first construct is concerned with objectives of the proposed physical education and sports program for sports recreation specialists working in the disability field which includes 4 items, the second construct relates to targeted educational outcomes of the proposed physical education and sports program for sports recreation specialists working in the disability field and involves 15 items, the third construct is concerned with contents of the proposed physical education and sports program for sports recreation specialists working in the disability field and consists of 14 items, the fourth construct is associated with working fields of the proposed physical education and sports program for sports recreation specialists working in the disability field and includes 3 items, the fifth construct relates to teaching and learning methods that will be 
employed in the proposed physical education and sports program for sports recreation specialists working in the disability field and involves 10 items, and finally the sixth construct which is concerned with evaluation methods of the proposed physical education and sports program for sports recreation specialists working in the disability field and consists of 6 items.

\section{Recommendations}

1- $\quad$ Accredit the proposed physical education and sports program which is designed for sports recreation specialists working in the disability field and implement the proposed program after accreditation.

2- Setting up criteria, conditions and rules to enroll in the proposed physical education and sports program for sports recreation specialists working in the disability field in accordance with quality criteria and the needs of business market.

3- Organizing and implementing workshops in different faculties and specialties for beneficiaries of the proposed program in order to enhance their abilities according to the needs of business market.

\section{References}

1- Ibraheem Shawky (2003) problems of professional preparation-problems of students in United Arab of Emirates students- Psychology department in Cairo University and UAE University, published in Journal of Humanities and Social sciences

2- Eman Refaat Elsaeed (2012) the effectiveness of a program for preparing sports recreation specialists, published paper, Scientific Journal of Physical and Sports Education, Vol. 64, library of Faculty of Physical education for males, Helwan University

3- Tamer Ahmed Abdelhameed (2014) Teaching and learning strategies in light of basic education quality, unpublished dissertation, library of Faculty of Physical education for males, Helwan University

4- Tahany Mohammed Abdelsallam, Basics of recreation and recreational education, Dar Elfekr Elaraby, Cairo, 2001

5- Hanan Fayz Mahmoud, (2004) A proposed recreational program and its effect on developing self-awareness for children with intellectual disability, unpublished thesis, faculty of Physical education for females, University of Alexandria

6- Sally Saeed Abdo (2014) Evaluation of sports management programs in accordance with ruling standards and graduate qualifications, unpublished dissertation, Faculty of Physical Education for females, Helwan University

7- Shimaa Mohamed Yahia (2012) Effective management of Human resources and its role in quality performance and satisfaction of beneficiaries in health clubs

8- Abdelhammed Mohamed Fathy (2011) A proposed curriculum for recreational tourism for Faculty of Physical Education students, Recreational Department, unpublished dissertation, Faculty of Physical Education for females, Alexandria University

9- Mohammed Abdeltawab Abu Elnour (2009) Challenges of applying total quality management in higher education, Special issue, Seventh International Conference " Education in third millennium: quality - availability - lifelong learning", Vol.3, Educational Studies Institute, Cairo University

10- Mohammed Kamal Elsamanody (2001) Applications in recreation and leisure, Matbaaa Elforssan, Elmansoura 
11- Mohammed ElHamahmy and Ayda Abdelaziz (1998) Recreation: Theory and Applications, Markas Elketab for publishing, Cairo

12- Mohammed ElHamahmy and Amin Elkhouly (2001) Basics of developing sports recreation programs, third edition, Cairo, Dar Elfekr Elaraby

13- Mahmoud Sayed Hashim (2010) Developing Sports for All programs in light of total quality management, Unpublished dissertation, library of Faculty of Physical Education for males,, Helwan University

14- AmlGamil Youssef, Mohamed Abd El salaam (2011) : Professional Development Of Specialist in sports For All ( Recent Graduates ) In Light Of Labor Market Requirement, World journal of sports sciences, 1127, Vol. 6, N.2

15- Benjamin Jeffry Hartnell (2011) : Standards-Based Curriculum, Differentiated Instruction, and End of Course Assessments, Doctoral Study, COLLEGE OF EDUCATION, Walden University.

16- Carole, Veir: A Staff Development in Service Training Packet based upon the Texas Teacher Appraisal. Paper presented at the Annual Meeting of the American Education Research Association; Chicago, 2003.

17- Council On Accreditation (2004) :Standards and Evaluative Criteria, For Baccalaureate Programs in Recreation Park Resources and leisure Services.

18- Echevaria: In Service Training Needs of Teachers and principals of elementary schools of Purto-Rico, 2000. 